\title{
The Rise of Political Islam in Turkey: The Role of Socio-Psychological Factors
}

\author{
Eldar T. Hasanov
}

\begin{abstract}
The factors behind the rise of Islamism in Turkey remain the subject of intense scholarly debate. There are remarkable relationships between the rise of Islamism and preceding changes in population dynamics in Turkey. Rapid urbanization and large-scale migration of Kurds and other ethnic minorities from the east of the county to major cities in the west created a situation when Kemalist ideology, that was based on Turkish nationalism and secularism, could not continue to play its nation-building role. The increasing share of ethnic minority groups in major urban centers of the country created a need for a social transformation that can bring people with different ethnic identities together based on a shared aspect of their identity. There was a need for a bond that can link members of different ethnic groups to one another and to the country as a whole. This need found its realization in Islamism as the main shared aspect of the identity of the majority of ethnic Turks and Kurds is their religion - Sunni Islam. Islamism offered a sense of a new superseding identity that helped to restrain existing Turkish, Kurdish and other ethnic identities and helped to reconcile and stabilize social relationships by reducing ethnic antagonism, tension and potential conflict. This new consolidating mechanism helped to create a state of a strong and substantial common ground between different ethnic groups concentrated in major metropolitan areas of Turkey. The rise of political Islam in Turkey was the political consequence of changing social preferences and motivation that resulted in inventing the reason for the social and political change, without recognizing and acknowledging the real underlying motives behind it. The fact, that many leaders of Islamic parties and movements in Turkey belong to ethnic minority groups, is another argument in favor of this proposed explanation. On the extreme end of the spectrum, religious extremism and radicalization, that are some of the adverse effects of the same processes, represent the high price that society has to pay for stabilizing its ethnic relations.
\end{abstract}

Keywords: Islamism, Turkey, Radicalization, Conflict, Religion, Nationalism, Muslim, Conflict, Identity. 
After the collapse of the Ottoman Empire, Turkey became a nation state with the new ideology that was introduced by Mustafa Kemal Atatürk, the founder of the Turkish Republic. This Kemalist ideology was based on Turkish nationalism and secularism and the country initiated an extensive program of political, economic and cultural reforms with the ultimate goal of building a modern and secular nation state. These reforms influenced every aspect of Turkish society, wiping out the legacy of dominance long held by religion and tradition. As part of the reforms, the country's official history and language were revised. A new education system glorified pre-Islamic Turkic civilizations at the expense of the country's more recent Ottoman past, and many Arabic and Persian words were purged to create an "authentically" Turkish vocabulary. The country had preserved and maintained its secular identity for many decades until the unexpected rise of Islamism over recent decades increased the role of religion in Turkish society. Political Islam started to become increasingly popular in the early 1990s. In the March 1994 local elections, the Islamist Welfare Party won the mayor's office in 28 municipalities, including Turkey's two largest cities, Istanbul and Ankara. ${ }^{1}$ In the 1995 national elections, Islamist Welfare party came in first again ${ }^{2}$. For the first time since the founding of the Turkish Republic in 1923, Turkey was run by an Islamist party, with an Islamist prime minister. After the Welfare Party was banned, another Islamist party AKP came to power in November 2002. What caused the reversal of the secularization trend in Turkish history that dominated the country for many decades since its foundation?

During the last several decades, Turkey has experienced fast rates of urban growth and the rapid population shift from eastern Kurdish-populated provinces to major urban areas in the western provinces of the county. In comparison to European countries, the average size of a large metropolitan city in Turkey is over 1.1 million inhabitants, nearly twice as large as the EU average and greater than any other country in Europe ${ }^{3}$. Within the Turkish cities, large urban centers dominate, where the core cities host 34 percent of the country's population ${ }^{4}$. In the early 1950 s, only $25 \%$ of Turkey's population lived in

\footnotetext{
${ }^{1}$ Angel Rabasa t F. Stephen Larrabee, "The Rise of Political Islam in Turkey" p.42

${ }^{2}$ Id.

3 "World Bank. 2015. Rise of the Anatolian Tigers : Turkey Urbanization Review, Main Report. Policy brief;. Washington, DC. (c) World Bank. https://openknowledge.worldbank.org/handle/10986/22388 License: CC BY 3.0 IGO. p.9

${ }^{4}$ Id.
} 
urban areas. And by 2015 the urbanization rate in Turkey reached almost $75 \%^{5}$. Among those migrants, a large percentage comprised of ethnic minorities represented largely by Kurds. According to estimates the population range of Kurds in Turkey is between $12,600,000$ to $19,000,000$ and some sources estimate that up to $25 \%$ of Turkey's population is Kurdish ${ }^{6}$. Because of higher fertility rates in Kurdish-populated eastern provinces ${ }^{7}$ the share of Kurds in total population has been steadily increasing and some observers believe Kurds could become the majority in Turkey within another generation ${ }^{8}$. Before 1980s Kurds predominantly lived in eastern provinces of the country, but due to the migration to the big cities in the west of Turkey, the significant part of Kurdish population of Turkey now live outside Kurdish-populated eastern provinces. The number of residents of Istanbul originating from some Kurdish-populated eastern provinces is greater than the populations of their entire respective provinces ${ }^{9}$. According to some estimates, the number of Kurds in Istanbul is more than 4 million people ${ }^{10}$, making the city the largest Kurdish populated city in the world. According to another estimation, Kurds in Istanbul, Ankara, Izmir and other big cities outside Kurdishpopulated provinces constitute $35 \%$ of the total Kurdish population of Turkey ${ }^{11}$. Since the population shift to the big cities in the west of Turkey, interethnic marriage has become more common. A recent study estimates that there are 2,708,000 marriages between Turks and Kurds ${ }^{12}$.

This massive migration of Kurds and other ethnic minority groups to large metropolitan areas coincided with the rise of Islamism in political, social and cultural spheres in Turkey. The proportion of those in Turkey calling themselves "very religious" was only $6 \%$ in 1999 , this increased to $13 \%$ in the 2006 research. Likewise, while the proportion who first

\footnotetext{
5 "World Bank. 2015. Rise of the Anatolian Tigers : Turkey Urbanization Review, Main Report. Policy brief;. Washington, DC. (c) World Bank. https://openknowledge.worldbank.org/handle/10986/22388 License: CC BY 3.0 IGO.p.10

${ }^{6}$ Sandra Mackey, "The reckoning: Iraq and the legacy of Saddam", W.W. Norton and Company, 2002. p 350

${ }^{7}$ Turkish Statistical Institute (TurkStat) (2012-08-31). "Turkish Statistical Institute Birth Statistics 2012".

Turkstat.gov.tr.

${ }^{8}$ https://www.ibtimes.com/turkey-high-kurdish-birth-rate-raises-questions-about-future-705488

9 "Population and Demographic Structure". Istanbul 2010: European Capital of Culture. Istanbul Metropolitan Municipality. 2008.

${ }^{10}$ John Tirman (1997). Spoils of War: The Human Cost of America's Arms Trade. Free Press. p21 ISBN 978-0-684-82726-1.

${ }^{11}$ Lokman I. Meho (1 January 1997). The Kurds and Kurdistan: A Selective and Annotated Bibliography. ABC-CLIO. pp. 2ISBN 978-0-313-30397-5.

${ }^{12}$ Kurdish Life in Contemporary Turkey: Migration, Gender and Ethnic Identity, Anna Grabolle Celiker, p. 160, I.B.Tauris, 2013
} 
described their identities as "Muslim" was $36 \%$ in 1999, this rose to $45 \%$ - an increase of $10 \%{ }^{13}$. Starting in the early 1990s, Islamist parties began to win greater and greater percentages of the vote. In the March 1994 local elections, the Islamist Welfare Party came first and won the mayor's office in some of Turkey's largest cities ${ }^{14}$. In contrast, in the mainly rural and underdeveloped Kurdish-populated south-eastern provinces left-wing, secularist parties are more popular ${ }^{15}$. So is there any cause and effect relationship between the largescale migration of minority groups to major cities and the subsequent rise of Islamism in the political, social and cultural life of Turkey?

In one of classic social psychology experiments named Robbers Cave Experiment conducted by Muzafer Sherif, two groups with different identities were in antagonistic opposition to each other and simple interactions between the groups were not enough to overcome the tensions and negative feelings between them ${ }^{16}$. These two groups could successfully reduce tensions and come together only after finding common ground in superordinate goals, that helped to suppress old identities and reinforced the sense of community between two groups. It is interesting to draw an analogy between Sherif's Robbers Cave Experiment and the social and political transformation that has taken place in Turkey.

Sherif's experiment had three phases. In the first stage, twenty-two eleven-year-old boys were taken into a summer camp where they were randomly divided into two groups. The two groups were housed in cabins in different areas of the Robbers Cave State Park in Oklahoma without being aware of the existence of each other. By the end of the first phase of the experiment, each group developed its own identity and sense of belonging to the group. Each group had its own name that was put on their flag and shirts. One of the groups chose Rattlers as their group name and the other group chose Eagles ${ }^{17}$.

During the second stage, the two groups came into contact with each other. This phase included some competitive games activities between the groups with prizes for the members of the winning group. Conflict situations between the two groups became

\footnotetext{
${ }^{13}$ Religion, Society and Politics in a Changing Turkey. Ali Çarkoğlu 2007 TESEV Publications, 2007 p101.

${ }^{14}$ Angel Rabasa t F. Stephen Larrabee, "The Rise of Political Islam in Turkey" p.42

${ }^{15} \mathrm{http}: / /$ www.hurriyetdailynews.com/hdp-passes-electoral-threshold-keeps-seats-in-parliament-133738

${ }^{16}$ Sherif, M., Harvey, O.J., White, B.J., Hood, W.R., \& Sherif, C.W. (1961) Intergroup Conflict and Co-operation: The Robbers Cave Experiment. Norman, OK: University of Oklahoma Book Exchange.

${ }^{17}$ Id.
} 
apparent. During this step, the antagonism between the two groups seriously increased. At some point, the clashes between the two groups became so hostile that the researchers had to intervene in order to separate them. The researchers decided that it was not safe to conduct friction-producing activities and phase two was cut short and phase three started.

The third phase was the most insightful and important part of the experiment. In this phase, the researchers tried to find ways to bring about collaboration between the two groups following a stage of intergroup conflict and tensions. The purpose of this stage was to explore the process of resolution of conflicts between the two groups. This phase started with a number of reconciliatory opportunities like the watching of a movie and so on. Some of these activities had actually ended in fights again. Sherif established that contacts between the two groups by itself is not enough to decrease tensions. In order to reconcile the two groups, they needed to create a state of genuine and substantial interdependence between the two groups by having superordinate goals. Finding common ground helped to reinforce new combined group identity and weaken old group identities.

The insights gained in this experiment can be applied to the socio-psychological dynamics of Turkish society over the past several decades. The first stage of the experiment corresponds to the 1960s and 1970s - the period in Turkish history when the majority of its population lived in predominantly mono-ethnic villages and towns with a little direct contact between different ethnic groups of the country.

The second phase has parallels to the 1980s. During this period Turkey experienced the rapid urbanization and the large-scale migration of Kurds and other ethnic minorities from rural eastern provinces of Turkey to its major cities in the west of the country. This period in Turkish history also marked by an armed conflict between the government and various Kurdish insurgent groups led by The Kurdistan Workers' Party (PKK). During this period Turkey was polarized between Turkish versus Kurdish identities.

The third phase is comparable with the 1990s and 2000s. During this period the percentage of urban population has grown to more than $70 \%{ }^{18}$ and Kurds and other ethnic minorities constituted a considerable proportion of the population of all major cities in

\footnotetext{
18 “World Bank. 2015. Rise of the Anatolian Tigers : Turkey Urbanization Review, Main Report. Policy brief;. Washington, DC. @ World Bank. https://openknowledge.worldbank.org/handle/10986/22388 License: CC BY 3.0 IGO.p.10
} 
Turkey $^{19}$. The increasing tensions brought on by ethnic polarization could not be resolved within the existing predominantly secular nationalist socio-political climate. These changes in demographics created a need for a social transformation that can bring people with different ethnic identities together based on a shared aspect of their identity. There was a need for a bond that can link members of different ethnic groups to one another and to the country as a whole. This need found its realization in Islamism because the main shared aspect of the identity of the majority of ethnic Turks and Kurds is their religion - Sunni Islam. Islamism offered a sense of a new identity that helped to restrain existing Turkish, Kurdish and other ethnic identities and helped to create a state of strong and substantial common ground between the different ethnic groups concentrated in major densely populated metropolitan areas of Turkey. It helped to reconcile and stabilize social relationships by reducing ethnic tension, competition and potential conflict. Similar to the Robbers Cave Experiment where conflicting groups come into cooperation and integration through the attainment of superordinate goals, ethnic Turks and Turkey's ethnic minorities found their superordinate goal in the increased role of religious identity. This change in the way the Turkish society behaved and the values and norms to which it adhered came despite the strong secularist tradition that dominated the country for many decades since its foundation. The rise of political Islam in Turkey was the political consequence of changing social preferences and motivation that resulted in inventing the reason for the social and political change, without recognizing and acknowledging the real underlying motives behind it.

For millions of Kurds and other ethnic minorities, that migrated to the big cities, upholding their religious identity as opposed to ethnic identity alleviated the acculturative stress associated with pressures of losing native language and culture. At the same time embracing the country's predominant religion makes them feel less disloyal to their existing ethnic heritage because the increased role of the Islamic part of their heritage compensates the diminishing ethnic part. As a result, the process of assimilation does not produce significant negative impacts on self-respect and self-esteem of the members of minority communities. The fact, that many leaders of Islamic parties and movements in Turkey belong to ethnic minority groups, is another argument in favor of this proposed explanation.

\footnotetext{
${ }^{19}$ https://www.ibtimes.com/turkey-high-kurdish-birth-rate-raises-questions-about-future-705488
} 
For the host Turkish population, the rise and development of Islamism at the expense of Turkish nationalism make it easier to welcome new waves of internal migrants belonging to ethnic minorities. It helped to transcend Turkish nationalism, curtail xenophobia and minimize racial prejudice, ethnic discrimination and segregation against Kurds and other minorities.

The spontaneous rise of Islamism in Turkey fueled by these subterranean sociopsychological forces was a way for evolving multi-ethnic society to increase social cohesion and solidarity by serving as a bond linking ethnic groups to one another and to the society and the country as a whole. Psychological research shows that ideologies may be based on unconscious motivational processes, in contrast with the point of view that political and social beliefs always have voluntarily nature reflecting independent and unbiased thinking based on free will. ${ }^{20}$

Capitalizing on religious identity made ethnic identity with its divisive force In the multiethnic society less important and thereby reduced the potential of escalation of ethnic conflicts similar to one led by Kurdistan Workers' Party - PKK. One of the reasons why Kurdish separatism in Turkey, led by PKK, is based on radical left anti-clerical ideology is because the opposite of this ideology - right-wing religious conservatism, cannot provide enough justification and rationalization for separatism as the majority of Kurds and Turks adhere to the same religion.

At first glance, the puzzlingly positive correlation between the urbanization and the rise of Islamism looks counterintuitive, as urban populations are generally more secular and less conservative than rural ones. This relationship cab be explained by the need of different ethnic groups, concentrated in densely populated urban areas, to find a common ground and sense of community.

Turkey is not the only country where urbanization and changes in population dynamics played a significant role in the rise of Islamism. In Iran, where the proportion of ethnic minorities is much higher than in Turkey, Shah's modernization reforms during the 1960s

\footnotetext{
${ }^{20}$ Jost, John T., Ledgerwood, Alison, \& Hardin, Curtis D. (2008). "Shared reality, system justification, and the relational basis of ideological beliefs." Social and Personality Psychology Compass, 2, 171-186
} 
and 1970s, fuelled by oil revenues, triggered massive populations move from rural to urban areas creating large ethnically diverse cities. The share of urban population in Iran during this period increased from $35 \%$ to almost $50 \%{ }^{21}$. As a result, the same underlying factors stimulated even more radical social change in the form of the Islamic revolution. In neighboring Afghanistan and Pakistan with very ethnically and tribally fragmented populations, without any ethnic group having an absolute majority, the commonality of the Islamic faith shared by the majority of people became the main nation-building force, binding people together and preventing ethnic and tribal conflicts. Among Muslim regions of former Soviet Union, Islamism gained strongest ground in Russia's autonomous republic of Dagestan. This region is the most ethnically heterogeneous republic in the country and strong influence of Islamism can also be attributed to its role as a consolidating factor among the region's many ethnic groups. And in North Africa Islamism facilitates the ongoing assimilation of Berber nations by strengthening religious aspect of their heritage and diminishing ethnic one.

The same factors, on the extreme end of the spectrum, brought about religious fundamentalism and radicalization, turning some countries and regions to the hotbed of terrorist activity by militant jihadist organizations.

${ }^{21}$ Iran Census Results 2011 Archived December 23, 2015 
